\title{
Applying the Main Concepts of Islamic Psychology to Islamic Counseling
}

\author{
Nooraini Othman \& Khairul 'Azmi Mohamad
}

To Link this Article: http://dx.doi.org/10.6007/IJARBSS/v9-i5/5878 DOI: $10.6007 / I J A R B S S / v 9-i 5 / 5878$

Received: 02 March 2019, Revised: 15 April 2019, Accepted: 04 May 2019

Published Online: 27 May 2019

In-Text Citation: (Othman \& Mohamad, 2019)

To Cite this Article: Othman, N., \& Mohamad, K. 'Azmi. (2019). Applying the Main Concepts of Islamic Psychology to Islamic Counseling. International Journal of Academic Research Business and Social Sciences, 9(5), 383393.

Copyright: (C) 2019 The Author(s)

Published by Human Resource Management Academic Research Society (www.hrmars.com)

This article is published under the Creative Commons Attribution (CC BY 4.0) license. Anyone may reproduce, distribute, translate and create derivative works of this article (for both commercial and non-commercial purposes), subject to full attribution to the original publication and authors. The full terms of this license may be seen

at: http://creativecommons.org/licences/by/4.0/legalcode

Vol. 9, No. 5, 2019, Pg. 383 - 393

Full Terms \& Conditions of access and use can be found at http://hrmars.com/index.php/pages/detail/publication-ethics 


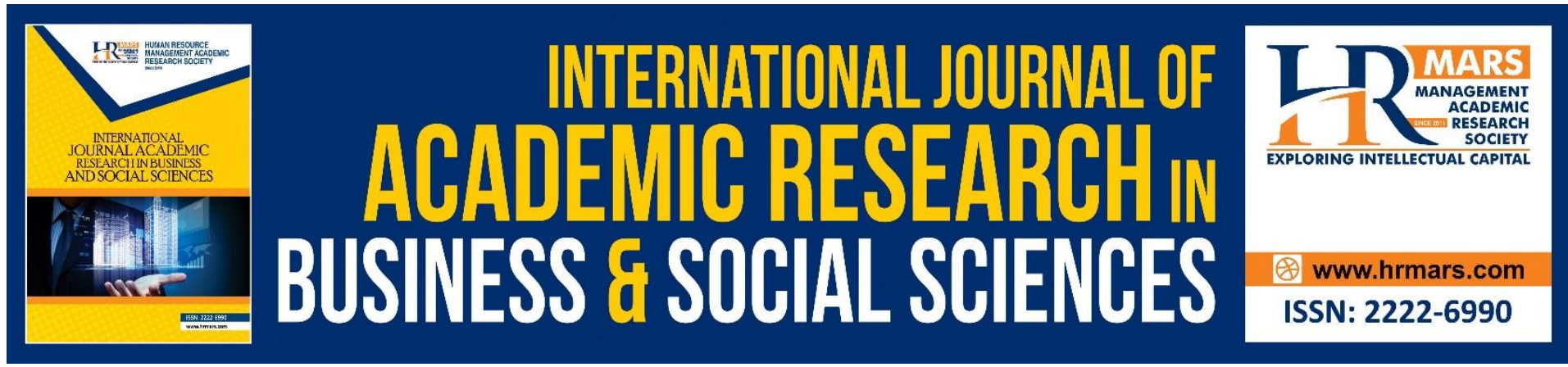

\title{
Applying the Main Concepts of Islamic Psychology to Islamic Counseling
}

\author{
Nooraini Othman ${ }^{1} \underline{\&}$ Khairul 'Azmi Mohamad² \\ Perdana Centre of Science, Technology \& Innovation Policy, Razak Faculty of \\ Technology \& Informatics, Universiti Teknologi Malaysia \\ Email: ${ }^{1}$ p-noraini@utm.my, ${ }^{2}$ khairulnooraini@gmail.com
}

\begin{abstract}
The aim of this paper is to discuss on the application of the main concepts of Islamic Psychology in the practice of Islamic Counselling. In order to reach that aim, the authors will highlight the main concepts in Islamic Psychology as to show how it is different from the conventional psychology. The concept of human nature and our goal in life will be elaborated in view of developing the personality of the Muslim Counsellors and their clients. The compatibility between the personality of the counsellor and his clients is important in ensuring the existence of congruency. Congruency is required to be one of the counsellor's characteristics in which the counsellor acts as a role model. Being a role model, he is needed to to be as real, transparent and genuine so as to provide the clients with the necessary strength and willingness to engage in honest and accurate self-exploration. Thus, it is vital for the Muslim counsellors to have the knowledge and understanding in the area of Islamic Psychology and be able to apply them in developing the spiritual inner self of the counsellors as well as in their clients.
\end{abstract}

Keywords: Islamic Psychology, Islamic Counselling, Human Nature, Personality, Congruence

\section{Introduction}

Psychology is the study of human mind, how it works and how it might affect the behaviour. It also refers to the application of the knowledge, which can be used to understand events, treat mental health issues, and improve education, employment and relationships. Primarily, it studies people and looks at why they think and act like one. Psychology allows human to understand more about how the body and mind work together. Thus, this knowledge can help with decision-making, avoiding stressful situations, time management, setting and achieving goals and the most important is to lead a happy and effective living (Philippe, 2017). He added that the science not only allows people to be more successful, but it can also impact their health. It helps people to tackle their mental illnesses so that they can continue living their lives. Many theories have been developed to make people understand their own selves. However, 
due to the human complexity, these efforts never stop at any point. Debates and discussions continues until now.

Psychology has been applied in many areas of study including education, counselling, health, biology, sports, business as well as politics. Psychology makes these areas more humane in terms of its application and help the people to be more positive, determined and make better decisions in life.

One of the important areas which apply the knowledge of psychology in helping other people with psychological issues is Counselling. Counselling refers to an interpersonal relationship which involved a form of interpersonal interaction between a congruent, knowledgeable as well as skilful individual (counsellor) to understand and assisting another individual (client) in solving his personal issues. Counselling will take place if an individual seeks psychological help from a qualified and registered person to handle a counselling session in order to discuss certain issues involving conflict or dilemma which prevent him from enjoying his life. Normally, an individual will only seek for help when they could not solve their own issues and this situation prevents him from performing his normal functions in life. As a counsellor, there are certain important and significant characteristics which are expected from him or her. Among them are unconditional acceptance of the client, congruent, empathy and honesty (Rogers, 1967). These characteristics form a basis for personality development among the counsellors. Generally, counselling is primarily concerned with the well-being of the mental health. The goals of counselling as stated by Corey (2013) is to change an individual's thought, feelings and behaviour. Thus, this paper aims to discuss on the application of the main concepts of Islamic Psychology in the practice of Islamic Counselling. The concept of human nature and the goal in human life will be expounded in view of developing the personality of the Muslim Counsellors and their clients.

\section{Prevailing Mental Health Issues in the Society}

There has been an increased in public as well as the government concern of mental health issues across the world. Good mental health is related to mental and psychological well-being. World Organization of Health (2018) works to improve the mental health of individuals and society at large includes the promotion of mental health well-being, the prevention of mental disorders, the protection of human rights and the care of people affected by mental disorders. It is further noted that the burden of mental disorders continues to grow with significant impacts on health and major social, human rights and economic consequences in all countries of the world.

Untreated and ignorant of mental health issues such as prolong and uncontrolled stress, worries, overthinking, negative feelings, unhealthy lifestyle and jealousy might lead to a more serious issues. World Health Organization (2018) has come out with a Mental Health Action Plan 2013-2020 in which it recognizes the essential role of mental health in achieving health for all people. It aims to achieve equity through universal health coverage and stresses the importance of prevention. Focus was also given to the teenagers' mental health issues. It is reported that almost 800,000 deaths by suicide occurred globally in 2016 in which men are 75\% more likely than women to die as a result of suicide and it occurs in adolescents and adults of all ages (World Health Statistics, 2018). 
In the case of Malaysia, the National Health \& Morbidity Survey (2017) reported in a study which was conducted among more than 30,000 of the Malaysian secondary school-going adolescents in March to May 2017. The Malaysian community composed of three main racial that is Malay, Chinese and Indian. The prevalence of depression, anxiety and stress were $18.3 \%, 39.7 \%$ and $9.6 \%$ respectively. The prevalence of depression was higher among males (18.9\%), those of Indian ethnicity (33.1\%), and respondents from the state of Selangor (22.6\%). The prevalence of anxiety was higher among females $(42.3 \%)$, those of Bumiputera Sabah ethnicity (47.3\%), and respondents from the state of Sabah (46.8\%). The prevalence of stress was higher among students studied in urban areas (10.3\%), females $(10.3 \%)$, those of Indian ethnicity (15.3\%) and respondents from the state of Selangor (12.5\%). As compared to the survey done in 2012, there is an increased in the prevalence of depression and anxiety and a reduction in stress. The increased might be associated with loneliness felt by the teenagers most of the time or always for the past 12 months. It is proposed that mental health promotion and prevention strategies should be focused on adolescents and their parents in order to reduce mental health problems in Malaysia.

Given the prevailing mental health issues, the counsellors play a very important role in helping their clients to overcome or manage their symptoms with the guidance. They could also help in developing strategies and skills such as coping mechanism in order to minimize as well as manage the psychological effects of the issues. Other than becoming an active listener, the counsellor should be able to help the clients in managing their stress by turning it from a disturbance into a motivation. The ability to develop resilience and inner strength among those affected by the mental health issues would certainly enable them to prevent themselves from further self-destruction.

\section{Goal in the Life of a Muslim}

As a Muslim, we have different set of goals in life. Whoever we are in this world, in the end of the day, our aim is to get as much blessings from Allah and to win His pleasure. The basic function of man is the worship of Allah. Being His vicegerent, he has to realise the principle of integration at its highest. His worship should be dynamic, consequential and comprehensive in its nature which means it should not be confined only to the act of prayer but also to the development of his personality in all dimensions and establishment of a pious society (Ansari, 2001).

Man being a special creation of Allah, carries a responsibility on his shoulders and being accountable to Him for his deeds in this worldly life. It is good to be reminded that human belongs to Allah and Allah is his final destination. Thus, looking at the nature of his functions on earth and his physical environment as well as being the vicegerent of Allah, he is expected to have an integrated personality in all the dimensions namely, physical, spiritual, moral, intellectual and aesthetical. Taking care of himself is as important as taking care of his fellowmen. The ability to fulfil his responsibility towards himself will create balance within himself and develop the congruence with his environment physically, mentally and psychologically. Ideally this is considered as a pre-requisite for the practising Muslim counsellors. The achievement of the five elements in al-maqasid as-syariah (higher objectives of syariah), namely, the protection of deen (Islam), nafs (self), aqal (mind), mal (wealth) 
and nasal (off-spring) become the important goals in every Muslim life. Therefore, the role of a Muslim counsellor is to assist his client in trying to achieve these goals in order to reach the state of psychological well-being. This effort should be considered as a part of promotion and prevention in mental health.

\section{The Concept of Human Nature in Islamic Psychology}

Having to understand the meaning of psychology, the question of what is Islamic psychology needs an answer. There are many questions being raised by the people around us on what is Islamic Psychology? Is it the same as Psychology from the the Islamic perspective? What is the difference between Malay Psychology or Chinese Psychology or Indian Psychology? Husain (2006), in his book stated that Islamic Psychology involving theoretical integration and practical application of Islamic principles concerning guidance and counselling, personality development, therapy, positive health and many other areas.

In the view of the present authors, the root of the difference lies in the source of the references. Islamic Psychology found its foundations from the Quran and Hadith. Its point of references is no other than these two sources. From these sources, the scholars of Islam expound the psychological meanings and conceptualized them into the understanding and practice of psychology. The conventional psychology provides us with many man-made theories which are based on the findings from the research, observations, experiments and perceptions. These theories were tested repeatedly by all researchers from all over the world. The outcomes of their research were in variety of forms such as new theories, models, modules, psychological testing as well as personality inventories which are widely used. We tend to forget or sometimes due to ignorance, we did not take into account the differences of culture and beliefs which finally influence the way we think, act, the upbringing and the practice. These are the weaknesses which we need to identify and understand in order for us the Muslims to learn from. It shows that not everything from the West is good nor they are all bad and cannot be adopted. Our task is to clear our mind and be openminded in accepting what is most suitable with our generations and our religion. Given that our source of reference and guidance is the Quran and Sunnah, we should be able to differentiate which one is good and can be adopted, and which one is not suitable with our way of life as prescribed by Islam. Thus, Islamic psychology provides us with a holistic view in understanding human nature as prescribed by the Quran and hadith.

The heart or Qalb, as Al-Ghazzali calls it, is the essence of man. According to Al-Ghazzali, the concept of the self is expressed in Arabic by four terms that is Qalb (heart), Ruh (soul), Nafs (desire-nature) and 'Aql (intellect, reason).

Mohamed (1996) explained although man is born in a state of fitra, he also has the potential of committing the wrongdoing, kufr (rejection of tawhid) and breaking the divine law. These are all part of the Divine scheme of Creation; their functions are important and decisive for man. Allah has endowed man with the inborn capacity to distinguish right from wrong through intellect, free will and revelation. Although man is not born evil, he is vulnerable to evil stimuli or external sources of misguidance. This property of the human constitution is intrinsic to man and is referred to as psyche or the self (nafs) of man. Thus, there is a need to keep both in a balanced state. 
Najati (1968a) explained about the existence of the conflict between animal and angelic characters in the human personality. Both are competing with one another in fulfilling their needs. Allah said in the Quran (An-Nazi'aat: 37-41),

"Then for him who transgressed all bounds (in disbelief, oppression and evil deeds of disobedience to Allah). And preferred the life of this world (by following his evil desires and lusts), verily, his abode will be Hell-fire. But for him who feared standing before his Lord, and restrained himself from impure evil desires and lusts. Verily, Paradise will be his abode".

Najati explained further that this conflict is a test from Allah for the human. Nik Hassan (1994) explained that the animalistic elements provide the energy for changes to take place, and the angelic elements are to ensure changes are in realm of human nobility. Those who are able to balance the needs derived from these aspects are those who belongs to the successful people and will be rewarded in this world and the hereafter.

Man is a special creation due to the spark of Allah's Spirit that makes him unique apart from the rest of creation. Allah said in the Quran (Al-Hijr:29):

"So, when I have fashioned him completely and breathed into him (Adam) of My soul, then fall (you) down to him in prostration."

In essence, Islamic Psychology is the study of mind, behaviour and spiritual well-being of a Muslim based on Quran and Sunnah.

\section{Applying Islamic Psychology in Counsellors and Clients Personality Development}

The Islamic personality, grounded in high moral character, encompass beliefs, external traits, attributes, behaviour, manners and social graces, and adab (Abdullah, 2005). It covers every aspect of interpersonal life, including relations between man and man, man and God, man and family, man and society, as well as man and the natural world. All of these are clearly reflected in the life stories of the Prophet, and are thoroughly documented in his seerah. The Islamic personality is a clear and distinct personality. Its fabric is the Book of Allah, and its thread is the Sunnah, and these two are inseparable from it. It is a sincere and determined personality educated and refined upon a precise methodology which does not contain even the slightest deficiency, and how could it since it is the Religion of Allah (Abdul Hameed, 1995).

It is clearly stated in the Quran (Ar-Rum:22) on the existence of individual differences based on genetic and environmental changes.

"And among His Signs is the creation of the heavens and the earth, and the difference of your languages and colours. Verily, in that are indeed signs for men of sound knowledge".

According to Najati (1968b; 1968c), the related verses and hadiths show that the differences among humans cover the physical aspects including the skin colour, shape and size as well as their potentials and emotions. Thus, the varieties in human body structure play a role in shaping the personality, especially from the emotional aspects. The Prophet himself stated that genetic and environmental factors play their 
own specific roles in creating individual differences. Individuals are categorised according to a certain set of traits with the intention to have a better understanding about human personality.

The present author in her previous research (Othman, 2008) developed a theoretical framework which is based on the Islamic worldview and the nature of man's creation in relation to the development of human personality. The worldview is the prior foundation of any action. Every human action is ultimately traceable to its worldview; and as such it is reducible ultimately to that worldview.

The Islamic view is that life must be guided by the principle of Tawhid (AlFaruqi, 1992). It is the testimony that Allah is the one and only God worthy of worship and that Prophet Muhammad is the final Messenger of Allah. It means that total obedience to the commands of Allah and adherence to the teachings of the Prophet would set a criteria par excellence in the life of a Muslim. The essence of Tawhid is to take the very words of Allah as revealed in the Quran, and the messages of the Prophet as contained in the hadith, as the guiding lights and principles of life. The challenge, however, is to translate them into every sphere of Muslim life. The changing reality of the world would certainly provide enough challenge to fulfil the task. No matter how complex life would be, the dynamics of Islamic teachings would always be relevant.

Human personality in the Islamic tradition is understood through the total makeup of human being - body, mind and soul. To understand the overall psychological nature of man and his personality development, one must understand the inner workings, the essence, of the whole person. The study of human personality will not be complete without understanding the factors which influence personality development. According to Najati (1968b), any research on biological factors, society and culture without including the study of the spiritual aspect will only lead to a vague description and shallow understanding about personality. The study on basic concepts of human nature and its potentials will lead the way in understanding human personality.

Raba (2001) in his study was of the view that human nature is the bedrock for the development of human personality. The focus of his study was to unravel the impact of human nature as an underlying factor that brings about different personality types. The Holy Quran points out that man was created for a special purpose, hence he is equipped with faith as well as the necessary knowledge and potential that enables him to accomplish his mission on earth as a servant of Allah (swt). Faith and belief in Allah (swt), the capacity to learn, to do good and otherwise, to bear responsibility, to love, to acquire wealth and power, are inherent in his duties on earth.

Man has a dual nature that is body and soul (Al-Attas, 1990). According to Langgulung (2001), man is a being composed of clay, which belongs to the world of creation and subject to motion, change and alteration, bound by time and space. The ruh, which belongs to the world of command, is free and not limited by these two binding factors. Man is composed of body and spirit. The spirit is transcendent and is the centre of man's being. The soul is attached to the body in its downward tendency and to the spirit in its upward or spiritual tendency. According to the Quran, all psychological phenomena originate in the self. The self is the essence of man, and is often referred to by one of four terms in Arabic; qalb (heart), ruh (soul), nafs (desire- 
nature) and 'aql (intellect/reason) (Al-Ghazali, 1988). Each of these signifies spiritual entities.

These concepts are summarised in the following diagram which shows the relationships in what is termed the Ummatic Psycho-Spiritual Model.

Figure 1: $\quad$ The Ummatic Psycho-Spiritual Model in Human Personality Development

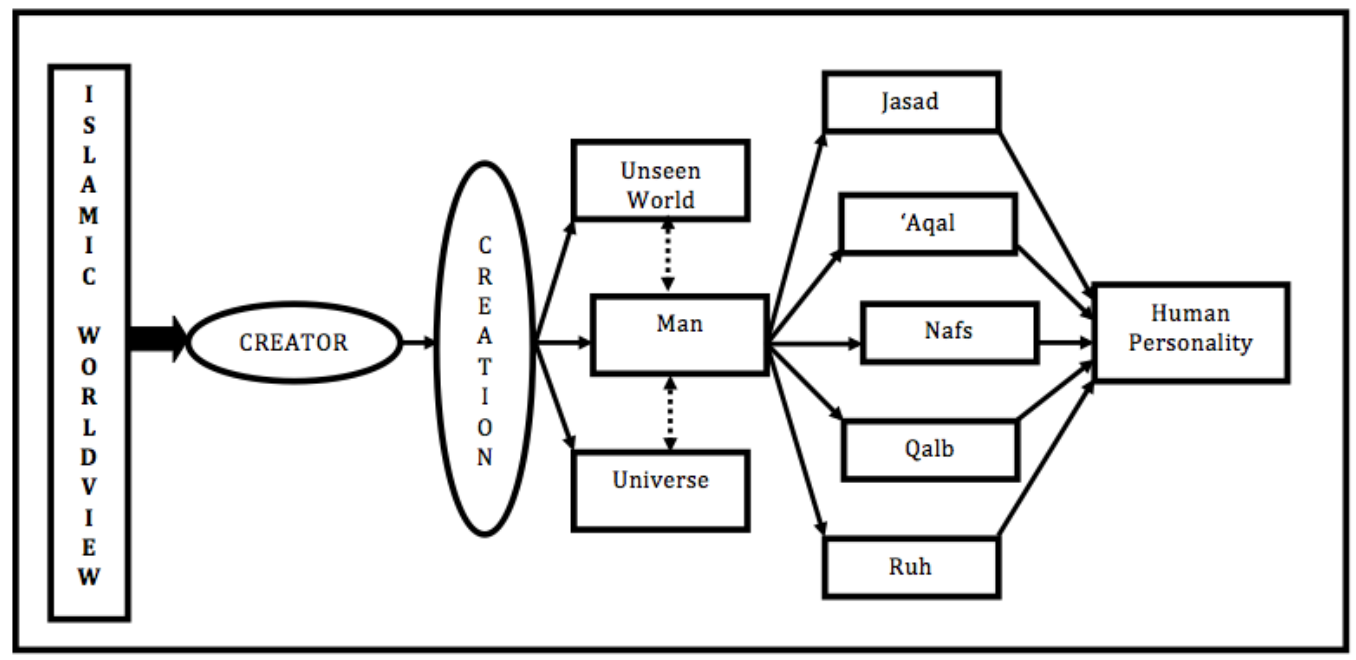

Source: Nooraini Othman (2008). Development and Validation of Ummatic Personality Inventory. An Unpublished PhD Thesis.

Gombak: International Islamic University Malaysia.

The functions of the Muslim counsellors are closely related to their goal in life, personality and characters. Nobody could deny that their responsibility to help their clients in achieving the psychological balanced and well-being is a big contribution to the client's current and future life. It is already Islamic in nature. Not only his own life but also his family, the society as a whole and the most important is his aqidah. Imagine an 18 years old Muslim teenager who came to a counsellor admitting that she wants to commit suicide due to peers' rejection. The ability of the counsellor to have the empathy, to comfort and develop the belief that she is worthy and useful would change the whole perspective about herself. To create the awareness to love her self means to love Allah requires a strong Islamic personality, which is congruent with the environment. The trust from the client would be developed based on the honesty felt in the client's heart for only a sincere and pure heart could send the most sincere message to another heart. Thus, it is clear that Islamic personality of the counsellor should be strengthened to enable him to be the role model to his clients. The sincere act of helping the clients in view of getting the blessing of Allah without any hope for physical rewards would increase the opportunity to serve those who are in need. The congruency between the counsellor's personality and his clients allows the process to be a therapeutic, healing and psychologically supportive in ensuring the counselling session achieves its aims.

\section{Conclusion}

The concepts of human nature in Islamic psychology could be a foundation in developing the personality of the counsellor and the client. Knowing that as a human, 
we are composed of these five elements, which inter-related to each other. In the effort to perform like a perfect Muslim, the struggle that every Muslim is facing could be materialised by understanding and internalising the function of each of these elements. A healthy soul (ruh) will be able to produce a good heart (qalb). A good heart (qalb) will develop a wisdom $(a q /)$. Wisdom (aql) will shape a wonderful self (nafs). A wonderful self (nafs) will develop a beautiful akhlaq and this beautiful akhlaq will remain to be the best of a Muslim personality.

A Muslim counsellor who works and performs only to seek the blessing of Allah throughout his whole life will always strive his best to help and assist his clients in the best possible manner, using his best to gain more knowledge, to master the counselling techniques and upgrading his skills to suit the needs of his clients. To be effective, counsellors should exhibit generic characteristics such as good psychological health, self-awareness, open-mindedness, having empathy, unconditional positive regard, genuineness and congruence, non-judgemental, cultural sensitivity and competence (Rassool, 2016). These characteristics, when couples with the Islamic spiritual elements would certainly bring better outcome to the counselling sessions. As concluded by Rassool (2016), Islamic counselling is a consciousness awareness of God in the counselling process in which it is based on the implicit understanding of a mutual belief system (Islam) shared by both the client and counsellor, which creates a trusting relationship between them. Thus, the practice of Islamic spirituality in the counsellor self, heart, mind and soul will develop a counsellor with Islamic personality and become the role model to his or her clients.

\section{Acknowledgement}

This research is sponsored by the Ministry of Education Malaysia under Fundamental Research Grant Scheme (FRGS), Vot No. 5F018 
INTERNATIONAL JOURNAL OF ACADEMIC RESEARCH IN BUSINESS AND SOCIAL SCIENCES

Vol. 9, No. 5, April, 2019, E-ISSN: 2222-6990 @ 2019 HRMARS

\section{References}

Abdullah, A. L. 2005. Towards the concept of Islamic personality. Retrieved on 23 November, 2005 from http://www.crescentlife.com/articles/islamic\%20psyc/concept_of_islamic_personality.htm

Hameed, A. S. A. H. A. (1995). The Islamic personality. United Social and Behavioural Sciences. Lanham: Rowman \& Littlefield Publishers, Sons Ltd.

Al-Attas, S.M.N. (1990). The nature of man and the psychology of the human soul. Kuala Lumpur: International Institute of Islamic Thought and Civilisation.

Al-Faruqi, I. R. (1992). Al-Tawhid: Its implications for thought and life. Virginia: International Institute of Islamic Thought.

Al-Ghazali. (1988). Ihya Ulumiddin (Vol. 1). (Yakub Ismail). Kuala Lumpur: Victory Ajensi.

Al-Harran, S. (2004). For today's sociall ills. Islam is the solution. Kuala Lumpur: A. S.

Noordeen

Ansari, M. F. R. (2001). The Quranic Foundations and Structure of Muslim Society. Volume 1. Kuala Lumpur: Islamic Book Trust

Corey, G. (2013). Theory and practice of counseling and psychotherapy ( $9^{\text {th }}$ ed.). USA: Thomson Brooks

Langgulung, H. (2001). A psycho-pedagogical approach to islamization of knowledge. Selangor: International Islamic University Malaysia.

Langgulung, H. (2001). A psycho-pedagogical approach to islamization of knowledge. Selangor: International Islamic University Malaysia.

Husain, A. (2006). Islamic psychology: Emergence of a new field. New Delhi: Global Vision Publishing House.

Mohamed, Y. (1996). Fitra: The Islamic concept of human nature. London: TaHa Publishers Ltd.

Najati, M. U. (1968a). 'Ilmu an-nafs al-Islami. Mesir: Darus Syuruk.

Najati, M. U. (1968b). Al-hadith an-nabawi wa 'ilmu an-nafs. Mesir:

DarusSyuruk.

Najati, M. U. (1968c). Al-Quran wa 'ilmu an-nafs. Mesir: Darus Syuruk.

National Health and Morbidity Survey 2017. Adolescent Mental Helath (Dass-21). Kuala Lumpur: Ministry of Health Malaysia

Nik Hassan, N. M. (1994). The relevance of human centred development in the industrial era. IKIM Journal. 2 (1), 79-92.

Othman, N. (2008). The Development and Validation of the Ummatic Personality Inventory. Skudai: Universiti Teknologi Malaysia Press.

Phillipe, R. (2017). The importance of psychology. Retrieved on 20 October 2018 from https://owlcation.com/social-sciences/Psychology-and-its-Importance

Raba, A. M. (2001). Major personalities in the Quran. Kuala Lumpur: A. S. Noordeen.

Rassool, G. H. (2016). Islamic counselling: An introduction to theory and practice. New

York: Routledge.

Rogers, C. R. (1980). A way of being. Boston: Houghton Mifflin.

World Health Organization (2018). Mental Health Action Plan 2013-2020. Retrieved

on 20 October 2018 from 
INTERNATIONAL JOURNAL OF ACADEMIC RESEARCH IN BUSINESS AND SOCIAL SCIENCES

Vol. 9, No. 5, April, 2019, E-ISSN: 2222-6990 @ 2019 HRMARS

https://www.who.int/mental_health/world-mental-health-day/2018/en/

World Health Statistics (2018). Monitoring health for the SDGs, sustainable development goals. Geneva: World Health Organization 